特集 2 解題

\title{
鈴木広と奥田道大の都市社会学と現在
}

\section{Contribution of Hiroshi Suzuki and Michihiro Okuda to Current Urban Sociology}

\author{
松尾浩一郎
}

\section{Koichiro MATSUO}

「鈴木広と奥田道大の都市社会学と現在」と題した特別セッションが持たれたのは、 2016 年 9 月 3 日の佛教大学紫野キャンパス、日本都市社会学会第34回大会においてであつ た。そこで展開された議論をもとしにて編まれたのが本特集である。特別セッションにお いて登壇されたのは、報告者の田中重好氏と玉野和志氏、討論者の山下祐介氏と渡戸一郎 氏の 4 人の方々であつた。ここに収めたのは報告者のおふたりにご寄稿いただいた 2 本の 論考である1)。

特別セッションの、つまり本特集の主題となるのは、そのタイトルのとおり鈴木広と奥 田道大というふたりの都市社会学者である。両者は長らく都市社会学界をリードする存在 として活躍してきた。鈴木は1931年生まれ、奥田は1932年生まれとほぼ同世代であり、 いずれも1950年代後半から研究活動を活発化させている。21世紀に至るまで質量とも傑 出した業績を積み上げていつた彼らの歩みは、ちょうど日本で都市社会学が興隆し定着し ていく過程と時期的に同期している。とくに、1982年に設立される日本都市社会学会にお いては、鈴木は設立当初から中心的な役割を果たし初代会長となっており、奥田も1991年 から 2 期 4 年にわたって会長を務めるなどし、ともに学会の舵取りという重責を担ってい る。2014年に鈴木と奥田が相次いで帰らぬ旅に赴かれたのに際して、綿々と続く都市社会 学の流れのなかに重要な区切りが打たれたと感じた者も、おそらく少なくなかったことで あろう。2016年の大会で特別セッションが企画されたのも、そうしたリアクションのひと つに他ならない。

その経緯はさておき、このようにして鈴木と奥田を取り上げるのは、都市社会学の来し 方を振り返ることでもある。しかし今このように都市社会学の歩从、学史に目を向けるこ とには、果たしてどのような意義があるだろうか。というのも、これまで日本の都市社会 学は一一るいは日本都市社会学会は一一折に触れて自らの過去を省みることを繰り返し てきている。とくに日本都市社会学会という組織に限っていえば、34年間の歴史のなか で、学会誌において日本の都市社会学を回顧する特集を 4 回にわたつて組んでおり、ま た、事実上それに近い内容となる特定の都市社会学者を主題にした特集がさらに 2 回あ 
る。合計すると6回を数えることになる2)。これほどまで繰り返し取り上げられてきた日 本都市社会学史を、今回この特集でさらに論じようとするのはいかなる意味を持つ試みな のだろうか。われわれはどのような意味を求めて鈴木と奥田が遺した仕事に向き合おうと すべきなのだろうか。3つ挙げたい。

まず第 1 に挙げたいのは、「都市社会学という「問い」」(町村 2013) の可能性を考える ための手掛かりとして、鈴木と奥田の研究は今なお大変に魅力的なものであり、われわれ はそこから多くのものを学び得ると思われることである。

ふたりはいずれもその長い研究歴を通して、「都市社会学という「問い」」の可能性をお し広げ、深めていこうとした。具体的な研究関心は狭い意味での都市のみに限られること はなく、鈴木は宗教や福祉や環境や災害などへと、奥田はエスニシティやグローバリゼー ション、さらにはエスノグラフィ論などへと議論を展開させていったが、その際にも「都 市社会学という「問い」」はしつかりと保持されていた。時には都市社会学の制度的な枠 組みを摇さぶったり越境していくこともあった。しかし、キャリアの後半期や晚年に至つ てからも都市社会学そのものを問おうとする意欲的な論考を発表していることからもわか るように（鈴木 1997、奥田 2009）、眼前の社会に対するアクチュアルな問題関心の追究 と、都市社会学へのこだわりを両立させ続けたことは、彼らの学問の真䯣のひとつとなつ ているといえるだろう。

そもそも都市社会学が学史をしばしば振り返ってきたのは、都市をめぐる激しく急速な 社会変容のなかで、「都市社会学という「問い」」の意味が摇らいでいるからでなかつただ ろうか。都市や都市社会や都市的なるものを問おうとするとき、都市社会学という問いの 立て方にはいかなる可能性があるのだろうか。こうした疑問の背後には、都市社会学とは いったい何なのかという問いも見え隠れしてくる。鈴木と奥田はこうした問いに対して、 それぞれの研究を通じ、それぞれの答えを身をもつて示し続けてきたのである。

第 2 に挙げたいのは、鈴木と奥田の研究を学ぶことを通じて、今日の都市社会学の基礎 的な共有財産となっているコミュニティ論について、改めて理解を深められると思われる ことである。

彼らはそれぞれ異なるスタイルで異なる問題に取り組んでいたが、両者ともコミュニ ティに焦点をあわせて自身の都市社会学を築き上げていつた点では軌を一にしている。い わゆる奥田コミュニティ・モデルは、とくに1970年代以降に広く活発に論じられるよう になるコミュニティ論を先導するレファレンスの役割を果たしたし、少し遅れて鈴木が提 唱したコミュニティ・モラールとコミュニティ・ノルムの概念は、サーベイ調査による実 証研究で活用するのに耐える強力な分析枠組となった。両者とも後年になると都市社会学 の枠には収まりきらないように研究関心を展開させているが、それでもその底流にはコ ミュニティに基礎をおく思考があった。しかしそれでいて、ふたりはコミュニティ概念を 用いてかなり異なる議論をしている。鈴木はコミュニティを土着型社会の一原型と捉え、 
その調査研究の結果から近代主義の虚妄性を見出していった ${ }^{3)}$ 。他方で奥田にとっては、 コミュニティに着目することは現代都市の先端を解きほぐすための鍵であり、都市コミュ ニティこそが都市社会学の普遍的な核心概念となるのであった ${ }^{4)}$ 。

都市を社会学的に研究しようとするとき、コミュニティが重要になるのは今も変わらな い。しかし今日のコミュニティ概念をめぐる状況をみると、社会一般にはますます広く浸 透している一方で、学界では議論の最前線からは退いている感がある。ここには思いのほ か深いギャップがあるのではなかろうか。そのような今であるからこそ、コミュニティ論 に再び光をあてることの新しい意義が高まっているといえるのではないだろうか。

第 3 に挙げたいのは、今日の都市社会学のあり方を枠づける影響力が鈴木と奥田にあっ たこと、つまりあえて極論すれば、彼らの研究が今日の都市社会学にとつての見えない足 枷になっている可能性もあることを、われわれは自覚していくべきではないかと思われる ことである。

ともに 1930 年代のはじめに生まれた鈴木と奥田は、日本の都市社会学にとつて唯一無 二の存在といえる特別な世代に属している。彼らの都市社会学者としての世代経験は、そ のすべてが日本都市社会学そのものだったといっても、あながち間違いではないであろ う。というのも、彼らが研究者としての道を本格的に歩みはじめた 1950 年代の後半は、 ちょうど都市社会学が一学問分野として急速に立ち上がろうとする時期であった。また、 日本都市社会学会の組織化に代表される学問分野としての制度化過程においては、彼らは 脂の乗つた働き盛りの世代として先頭に立つ役割を果たした。日本の都市社会学の誕生・ 成長・確立へと至るプロセス——れはやり直すことのできないユニークかつ決定的なプ ロセスである——は、鈴木・奥田世代の研究者個々人のライフサイクルとほぼ完全に一致 している。彼らはキャリアを通じて日本の都市社会学の最前列にいたのである。

いまある日本の都市社会学は、鈴木や奥田らの世代が築き上げ、その子供たちがさまざ まな展開を推し進めることで成り立ってきたといえるだろう。もちろん言うまでもなく、 さらに新しい世代の研究者が登場してくることも、学問としての一層の発展や変化も、と どまることなく続いていくであろう。だが、日本都市社会学を定義づけてきた鈴木や奥田 らの影響は、目に見える面においても潜在的な面においても、今のわれわれが考える都市 社会学という学問領域の存在そのものに深く刻み込まれている。その影響はいかなるもの であつたか。それが今日どのような意味を持つのか。彼らが遺したものを継承しようとす るにしても、あるいはそれを克服し乗り越えていこうとするにしても、まずそれらをあら ためて検証してみることが求められるであろう。

本特集に収められているふたつの論考について、ここで簡単に紹介しておきたい。 田中重好氏による「鈴木広の都市社会学がめざしたもの一三後の都市社会学の累積的 発展に向けて」は、鈴木による都市社会学研究の全体像を描き出した上で、そのなかでも 
核となる位置を占めているコミュニティ研究が、いかなる理論的視野を持ち、実証分析の 場でどのように展開していつたのかを詳細に跡づけている。鈴木はオリジナルなコミュニ ティ研究を切り開いた。そして、大都市のみに焦点が絞り込まれがちな視点を広く解放さ せ、地方の日常から「土着」の重要性を見出していったのである。

こうした議論を支えるのは、一般的にいって都市社会学には「その時々に社会が直面す る社会現象を、個別の問題意識をもって研究」するにとどまるという傾向があり、その結 果として、学問としての継承が十分になされていないのではないか、という田中氏の問題 認識である。鈴木の研究は、その時その時においてアクチュアルな問題に取り組みつつ も、そこからオリジナルな「都市社会学という「問い」」を見出し発展させていくよう な、より大きな視野から都市社会学を構想することにつながる懐の深さがあった。田中氏 は今後の都市社会学に向けて次のように投げかける。われわれのなすべきことは、鈴木の 業績を単に理解し引き継ぐことではなく、むしろ、鈴木のなかに見られる豊かな「「自ら 問いをつくる」力」を学ぶことなのだ、と。

玉野和志氏による「グローバリゼーションと都市研究——奥田都市社会学とコミュニ ティ」は、変化に富んださまざまな研究に取り組んだ奥田にも一貫した核があり、それは 都市性に焦点をあてる視点であり、都市コミュニティにおける共生の作法やその社会過程 に対する着目であることを指摘している。郊外住宅地、大都市インナーエリア、アジア系 外国人、シカゴ学派モノグラフなどと柔軟に研究対象を推移させていつたが、それらはい ずれも奥田にとってはコミュニティの探究に他ならなかつたのである。

このような奥田の確固とした立場は、彼の学問を強勒なものにした一方で、視野の限定 や偏りをもたらすことにもなつた。奥田はもつぱら眼前の都市で繰り広げられるリアリ ティの追究に注力した。そのため、海外の研究動向をフォローするときも、グローバリ ゼーションの研究に取り組むときも、「つねにドメスティックな観点」に立脚することに つながつた。それはまた、「都市という場における多様な生の展開に、素朴に関心を向け る」ことのみに留まるような研究の潮流が形成されていくことにもつながつたかもしれな い。玉野氏は以下のように問いかける。「奥田の都市社会学が、なぜか日本の都市社会学 研究をグローバルに位置づける普遍的な議論への回路を結果的に塞いでしまったことを、 われわれこそが重く受け止めなければならないのである」と。

鈴木広も奥田道大も、日本の都市社会学が今あるようなかたちを作るのに、きわめて大 きな役割を果たした。そのような意味で、ふたりは学史上の重要人物として永く記憶され るべき存在である。しかしそれだけではない。都市社会学のこれからに挑んでいかねばな らない私たちの前に、なおも向き合わなければならない「問題」として、ふたりの都市社 会学は現在も屹立しているのである。 
注

1）本セッションでの討論をふまえて書かれた渡戸（2017）も参照されたい。

2) 『日本都市社会学会年報』に見られる日本都市社会学史に関する特集を列挙すると、「鈴木栄 太郎の都市理論」(第 7 号、1989年)、「日本都市社会学の系譜と現在性」(第10号、1992年)、 「日本都市社会学における「社会調査」の系譜と課題」(第12号、1994年)、「磯村都市社会学 の今日的意義」(第16号、1998年)、「戦後日本の都市社会学一一回顧と展望」(第20号、2002 年)、「都市社会学——軌跡と展望」（第31号、2013年）を数えることができる。

3）鈴木（1986：166-8）は次のように述べている。「コミュニティ概念の中心は社会結合におけ る共同性と地域性であり、それはいうなれば、土着型社会の一原型であります。〔略〕総括的 にいって、一般に具体的な歴史的な社会現象、ないし社会過程は、土着要素と流動要素の組夕 合わせ、つまり衝突・協調・併存・競合のプロセスとしてこれを把握しうるというのが私の基 本的社会把握でして」、「調査の結果として「近代主義」の虚妄性が示唆されたということで す。逆にいうと土着の再評価です」。

4）奥田 (2006：111) は次のように述べている。「公共空間や公共世界その他のコンセプトが汎 用化された分、都市コミュニティのキーワードは後景に退いてきている感がある。日本都市社 会学会や地域社会学会レベルでは、都市コミュニティは戦後日本のキイワードの一つとして学 史（誌）上に記録されているが、筆者としてはハヤリスタリの用語とは別に、都市コミュニ ティのモデルじたいの再構築がいま求められている、と思う」。

\section{文献}

町村敬志, 2013, 「都市社会学という「問い」の可能性」『日本都市社会学会年報』31：5-20.

奥田道大, 2006,「都市コミュニティ研究のもう一つ先に一一覚え書きノート」, 広田康生ほか編 『先端都市社会学の地平』ハーベスト社.

奥田道大, 2009, 『人びとにとって「都市的なるもの」とは一新都市社会学・序説』ハーベス 卜社.

鈴木 広, 1986, 『都市化の研究——社会移動とコミュニティ』恒星社厚生閣.

鈴木 広, 1997, 「都市社会学の現代的課題」『久留米大学文学部紀要人間科学科編』11:21-34.

渡戸一郎, 2017, 「奥田都市社会学から何を継承するか」『明星大学社会学研究紀要』37：19-28. 